\title{
Preparation and characterization of a novel adsorbent from Moringa oleifera leaf
}

\author{
Olugbenga Solomon Bello ${ }^{1} \cdot$ Kayode Adesina Adegoke $^{1} \cdot$ Opeyemi Omowumi Akinyunni $^{2}$
}

Received: 9 August 2014/Accepted: 25 September 2015/Published online: 28 October 2015

(C) The Author(s) 2015. This article is published with open access at Springerlink.com

\begin{abstract}
A new and novel adsorbent was obtained by impregnation of Moringa oleifera leaf in $\mathrm{H}_{2} \mathrm{SO}_{4}$ and $\mathrm{NaOH}$, respectively. Prepared adsorbents were characterized using elemental analysis, FT-IR, SEM, TGA and EDX analyses, respectively. The effects of operational parameters, such as $\mathrm{pH}$, moisture content, ash content, porosity and iodine number on these adsorbents were investigated and compared with those of commercial activated carbon (CAC). EDX results of acid activated $M$. oleifera leaf have the highest percentage of carbon by weight $(69.40 \%)$ and $(76.11 \%)$ by atom, respectively. Proximate analysis showed that the fixed carbon content of acid activated $M$. oleifera leaf $(69.14 \pm 0.01)$ was the highest of all adsorbents studied. Conclusively, the present investigation shows that acid activated M. oleifera leaf is a good alternative adsorbent that could be used in lieu of CAC for recovery of dyes and heavy metal from aqueous solutions and other separation techniques.
\end{abstract}

Keywords Activation - Adsorbent - Characterization . Impregnation $\cdot$ Moringa oleifera $\cdot$ Pollutants

Olugbenga Solomon Bello

osbello06@gmail.com

1 Department of Pure and Applied Chemistry, Ladoke Akintola University of Technology, P.M.B 4000, Ogbomoso, Oyo State, Nigeria

2 Department of Industrial Chemistry, Osun State University, Osogbo, Osun State, Nigeria

\section{Introduction}

Large quantities of dangerous dyes, pigments and metals originated from dye manufacturing, textile as well as pulp and paper industries are emitted into wastewaters (Jain et al. 2003; Mittal et al. 2009a, b). This makes treating water contamination difficult, because the color tends to persist even after the conventional removal processes (Jain et al. 2003; Mittal et al. 2010a, b; Visa et al. 2010; Gupta et al. 2012a, b). The dye contaminations in water tend to prevent light penetration and, therefore, affect photosynthesis considerably (Banerjee and Chattopadhyaya 2013; Hameed et al. 2013; Hajati et al. 2014). Due to the wide application of dyes and their numerous hazards and toxic derivatives (Mittal et al. 2010a, b), the cleaning of wastewater from color dyestuff becomes environmentally important (Gupta et al. 2012a, b; Ghaedi et al. 2013). Although, synthetic origins aromatic dyes are even biologically non-degradable and their treatment by other effective conventional procedure is impossible (Mittal et al. 2009a, b; Saleh and Gupta 2012a, b).

There are several methods available for color removal from waters and wastewaters, such as membrane separation, aerobic and anaerobic degradation using various microorganisms, chemical oxidation, coagulation and flocculation, and reverse osmosis (Mittal et al. 2009a, b, 2010a, b; Gupta et al. 2012a, b; Karthikeyan et al. 2012). Some of these techniques have been shown to be effective; however, they have some limitations such as an excess amount of chemical usage, accumulation of concentrated sludge that has serious disposal problems and lack of effective color reduction (Jain et al. 2003; Mittal et al. 2009a, b; Saleh and Gupta 2012a, b). The adsorption technique, which is based on the transfer of pollutants from the solution to the solid phase, is known as one of the 
efficient and general wastewater treatment method (Gupta et al. 2011a, b; Ghaedi et al. 2012; Saleh and Gupta 2012a, b). The method is superior to other dye removal techniques in terms of initial cost, simplicity of design, ease of operation, and non-toxicity of the utilized adsorbents compared to other conventional wastewater treatment methods (Kismir and Aroguz 2011). The cost effectiveness, availability and adsorptive properties are the main criteria in the selection of an adsorbent to remove organic compounds from wastewaters (Demirbas et al. 2008; Ghaedi et al. 2012), also an application of adsorption procedure especially based on non-toxic and green adsorbent with high surface area and reactive surface atom is a great demand (Chiou and Chuang 2006).

Activated carbon, a widely used adsorbent in industrial processes, is composed of a microporous, homogenous structure with high surface area and shows radiation stability (Iqbal and Ashiq 2007; Mittal et al. 2010a, b). The process for producing efficient activated carbon is not completely investigated in developing countries. Furthermore, there are many problems with the regeneration of used activated carbon (Gupta and Nayak 2012). Nowadays, there is a great interest in finding inexpensive and effective alternatives to the existing commercial activated carbon (CAC) (Al-Othman et al. 2013). Exploring effective and low cost activated carbon may contribute to environmental sustainability and offer benefits for future commercial applications (Gupta et al. 2011a, b). The costs of activated carbon prepared from biomaterials are very low compared to the cost of CAC (Gupta and Nayak 2012). Waste materials that have been successfully used to manufacture activated carbon in the recent past include waste wood (Acharya et al. 2009), bagasse (Tsai et al. 2001), coir pith (Namasivayam and Kavitha 2002), orange peel (Khaled et al. 2009), Moringa oleifera tree (Kansal and Kumari 2014, Reddy et al. 2010), coffee husk (Ahmad and Rahman 2011), pine cone (Gecgel and Kolancilar 2012), mango peels (Bello and Ahmad 2011b); rice husk (Yahaya et al. 2010a, b, 2011a, b); periwinkle shell (Bello et al. 2008; Bello and Ahmad 2011c, d); coconut shell (Bello and Ahmad 2012b); Imperata cylindrica leaf (Bello and Semire 2012); rubber seed coat (Bello and Ahmad 2012a); banana stalk (Bello et al. 2012a); groundnut hulls (Bello et al. 2012b); ackee apple (Blighia sapida) seeds (Bello et al. 2013a, b); oil palm fruit fibre (Bello 2013); coconut tree (Senthilkumaar et al. 2006), sunflower seed hull (Thinakaran et al. 2008), pine-fruit shell (Royer et al. 2009), hazelnut husks, rice hulls, oil palm shell (Tan et al. 2008), and Coconut husk (Foo and Hameed 2012).

On the other hand, M. oleifera tree also known as a drumstick tree is a rapid growing deciduous shrub or small tree of about $13 \mathrm{~m}$ tall and $35 \mathrm{~cm}$ in diameter with an umbrella-shaped open cap (Anjorin et al. 2010). M. oleifera is the most widely distributed species of the Moringa ceae family throughout the World (Kansal and Kumari 2014; Reddy et al. 2010). When matured, the fruit becomes brown and has 10-50 seeds inside (Anjorin et al. 2010). The tree is native to India but has been planted around the world and is naturalized in many locales. It has also been reported (Hsu et al. 2006) that M. oleifera oil and micronutrients contain antitumor, antiepileptic, antidiuretic, anti-inflammatory and venomous bite characters. M. oleifera contains specific plant pigments with demonstrated powerful antioxidative ability such as vitamins $\mathrm{C}, \mathrm{E}, \mathrm{A}$, caffeoylquinic acids, carotenoidslutein, alpha-carotene and beta carotene, kaempferol, quercetin, rutin (Ho 1994; Siddhuraju and Becker 2003; Aslam et al. 2005).

In Nigeria, the usefulness of $M$. oleifera plant has been so recognized that the Federal Government of Nigeria has set up $M$. oleifera farm and it is found everywhere due to its medicinal values and ability to cure various ailments. However, to the best of our knowledge, there was no study on the characterization and the use of treated M. oleifera leaf as adsorbent. The objective of this paper is, therefore, to report the potential adsorptive capacity of raw and activated carbon produced, to analyze the moisture content, volatile matter, fixed carbon and ash contents in the precursor and to compare with commercially available expensive activated carbon.

\section{Material and methods}

\section{Carbonization of sample}

The dried $M$. oleifera leaves were carbonized in the Department of Pure and Applied Chemistry Laboratory of Ladoke Akintola University of Technology, Ogbomoso, Oyo State, Nigeria. $100 \mathrm{~g}$ of the dried sample was placed in a muffle furnace (Carbolite Sheffield, England, LMF4) and was heated at a rate of $350{ }^{\circ} \mathrm{C}$ for $2 \mathrm{~h}$. During the process, the steam was removed from the oven through the exhaust pipes. Under such oxygen-deficient conditions, the biomaterial was thermally decomposed to porous carbonaceous materials and hydrocarbon compounds. After cooling the activated samples to room temperature, it was washed with distilled water until constant $\mathrm{pH}$ of 7 was reached. The washed activated sample was then dried in an oven at $105{ }^{\circ} \mathrm{C}$ to constant weight. The final product was kept in an airtight polyethylene bag (Tarawou et al. 2007). The carbonized sample was sieved through a 100-mm mesh Tyler sieve. The fraction with size $106 \mu \mathrm{m}$ was collected and labeled as moringa leaf raw sample (MLR). 


\section{Activation of the carbonized samples}

Both acid and base activations were carried out in this study. A carefully weighed $15.0 \pm 0.01 \mathrm{~g}$ carbonized carbon was placed in a beaker containing $150 \mathrm{ml}$ of $0.1 \mathrm{~mol} /$ $\mathrm{dm}^{3}$ Sulfuric acid $\left(\mathrm{H}_{2} \mathrm{SO}_{4}\right.$; for acid activation) and $150 \mathrm{ml}$ of $0.1 \mathrm{~mol} / \mathrm{dm}^{3}$ sodium hydroxide $(\mathrm{NaOH}$; for base activation), respectively. The content of the beaker was carefully homogenized and allowed to stand for $24 \mathrm{~h}$. The already activated $M$. oleifera leaves was diluted with 200 $\mathrm{ml}$ of distilled water to rinse off the activating agents $\left(\mathrm{H}_{2} \mathrm{SO}_{4}\right.$ and $\left.\mathrm{NaOH}\right)$ used for impregnation. The process of washing was then repeated until the $\mathrm{pH}$ falls between 6.5 and 7.0. It was oven dried at $105^{\circ} \mathrm{C}$ for $4 \mathrm{~h}$ to constant weight. It was sieved with a $106 \mu \mathrm{m}$ mesh to obtain fine powdered M. olefera activated carbon for both acid (MLA) and base (MLB) respectively. They were kept in airtight vials and used for further studies.

\section{Proximate analysis (TGA)}

Thermogravimetric Analyzer (TGA) (Model Perkin Elmer TGA7, US) was used to analyze the moisture content, volatile matter, fixed carbon and ash contents in MLR, MLA and MLB samples respectively. Five grams of the sample was transferred into the platinum pan of the TGA analyzer. The furnace chamber was then raised and the sample was degassed for a few minutes. Nitrogen gas was allowed to pass through the furnace to ensure an inert atmosphere and the sample was heated from ambient temperature to $110{ }^{\circ} \mathrm{C}$ until a constant weight is obtained for the moisture content determination. The temperature was then increased to $850{ }^{\circ} \mathrm{C}$ and held for $7 \mathrm{~min}$. The temperature was then decreased to $800{ }^{\circ} \mathrm{C}$. The nitrogen gas was switched off while the oxygen gas was allowed to burn the sample. Fixed carbon content was determined from the weight loss during the burning stage. Ash content and the remaining mass were determined at the end of the analysis.

\section{Determination of $\mathrm{pH}$}

The standard test method for determination of activated carbon pH ASTMD3838-80 was used. $1.0 \mathrm{~g}$ of raw, acid activated and base activated M. oleifera was weighed and transferred into a beaker. $100 \mathrm{ml}$ of distilled water was measured, added and stirred for $1 \mathrm{~h}$. The samples were allowed to stabilize before the $\mathrm{pH}$ was measured using a $\mathrm{pH}$ meter. Samples were run in triplicates.

\section{Determination of the amount of Iodine adsorbed}

For the iodine number test, Gimba and Musa (2007) method was adopted. A stock solution was prepared containing $2.7 \mathrm{~g}$ of iodine crystals and $4.1 \mathrm{~g}$ of potassium iodide per liter. The prepared stock solution was standardized using a standard solution of sodium thiosulphate. To a $100 \mathrm{ml}$ volumetric flask, $0.5 \mathrm{~g}$ of the activated $M$. oleifera and $10 \mathrm{ml}$ of $5 \% \mathrm{v} / \mathrm{v}$ hydrochloric acid were introduced. The flask was swirled until the carbon was wetted. Then, $100 \mathrm{ml}$ of the stock iodine solution was added and agitated at a fast speed, using an electric shaker for a period of $60 \mathrm{~min}$. The mixtures were filtered through a sintered glass crucible. An aliquot portion $(20 \mathrm{ml})$ was titrated with $0.1 \mathrm{M}$ sodium thiosulphate using starch as an indicator. The concentration of iodine adsorbed by the activated M. oleifera at room temperature was calculated as the amount of iodine adsorbed in $\mathrm{mg}$.

$\frac{\mathrm{Img}}{\mathrm{g}}=\frac{(B-S)}{B} \times \frac{V M}{M} \times 253.81$,

where $B$ and $S$ are the volumes of thiosulphate solution required for blank and sample titrations, respectively. $W$ is the mass of activated $M$. oleifera sample, $M$ is the concentration (mol) of the iodine solute, 253.81 is the atomic mass of iodine and $V$ is $20 \mathrm{ml}$ aliquot.

\section{Fourier transform infrared (FTIR)}

Fourier transform infrared (FTIR) spectroscopic analysis was used to study the surface chemistry of both raw and activated M. oleifera using spectroscope (FTIR-2000, Perkin Elmer model). FTIR spectra were recorded between 4000 and $400 \mathrm{~cm}^{-1}$. The discs were prepared by first mixing $1 \mathrm{mg}$ of dried sample with $500 \mathrm{mg}$ of $\mathrm{KBr}$ (Merck, for spectroscopy) in an agate mortar and then pressing the resulting mixture at 10 tonnes $\mathrm{cm}^{-2}$ for $15 \mathrm{~min}$ under vacuum. The FTIR spectra give information about the characteristic functional groups on the surface of raw and activated M. oleifera.

\section{Electron dispersive X-ray (EDX)}

EDX is used for the elemental analysis/chemical characterization of the raw and activated $M$. oleifera. Its characterization capabilities are due to the principle that each element has a unique atomic structure, thus allowing a unique set of peaks on its X-ray spectra. The EDX allows the elemental composition of M. oleifera to be measured. 


\section{Results and discussion}

\section{Proximate analysis}

The samples were found to be rich in moisture and volatile matter. However, the moisture and volatile content were found to decrease significantly from raw to activated samples. During carbonization and activation processes, organic substances become unstable as a result of the heat causing the molecules to break their bonds and linkages. During activation step, volatile matter is released as gas and liquid products which evaporates off leaving a material with high carbon content (Ahmad and Alrozi 2010). Proximate analysis clearly indicates that the physiochemical activation has successfully increased the fixed carbon content and decreased the volatile matter (Table 1). The result for the proximate analysis: moisture, ash and volatile content in percentage, iodine number and $\mathrm{pH}$ is presented in Table 1.

\section{Mechanism of activation}

Acid and base activation of MLR sample decreases the ash content and leaves a number of tiny pores (Table 1). Simultaneously, $\mathrm{H}_{2} \mathrm{SO}_{4}$ and $\mathrm{NaOH}$ decompose the tissue of the carbon precursor; it also creates some new pores and voids. The activating agent permeates these tiny pores or voids, which increase the contact area between the activating agent and the carbon precursor. Consequently, this promotes the release of volatiles from the carbon structure and widens the micro pores in the original carbon structure, converting them into mesopores (Table 1). Activation also enlarges the micro pores, thereby increasing mesoporosity (Liou 2010).

\section{Surface characterization}

The proximate analyses presented in Table 1 show a low amount of moisture and volatile matter, and a relatively low amount of ash content, indicating that the particle density is relatively small and that the biomaterial should be an excellent raw material for adsorbents to be used in column or fixed-bed reactors (Ekpete and Horsfall 2011). High ash content can also affect activated carbon; i.e., it reduces the overall activity of the activated carbon. It also reduces the efficiency of reactivation, the lower the ash value; the better the activated carbon for use as adsorbent, but a high ash value reduces its efficiency (Bello and Ahmad 2012a, b).

\section{Iodine number}

Iodine number is a fundamental parameter used to characterize activated carbon performance. It is a measure of the micropore content of the activated carbon and is obtained by the adsorption of iodine from a solution by the activated carbon sample. The mesopores are responsible for the large surface area of activated carbon particles and are created during the activation process. It is in the mesopores that adsorption largely takes place (Bello et al. 2011).

Table 1 above suggested that the values of the iodine number obtained for MLB $(169.18 \pm 0.20)$ are lesser than the value obtained for CAC $(200.36 \pm 0.30)$, and the values of the iodine number obtained for MLR $(92.24 \pm 0.05)$ and MLA $(189.29 \pm 0.05)$ are lesser than the value obtained for CAC $(200.36 \pm 0.30)$. The higher the iodine number, the greater is the sorption capacity (Ekpete and Horsfall et al. 2011). According to the result obtained, it can be said that acid activated M. oleifera (MLA) is the best adsorbent when compared with both base activated $M$. oleifera (MLB) and raw M. oleifera (MLR). This is in agreement with the findings by some researchers (Horsfall et al. 2003; Adowei et al. 2012).

\section{Effect of pH}

The $\mathrm{pH}$ of MLR, MLA, MLB and CAC was found to be 7.08, 6.95, 7.02 and 7.0, respectively. It has been reported by Ahmedna et al. (2000) and Okieimen et al. (2007) that for most applications, carbon $\mathrm{pH} 6-8$ is acceptable. The $\mathrm{pH}$ values obtained are in the range of acceptable limit. The

Table 1 Comparison between the proximate content (physicochemical) analyses of MLR, MLA, MLB and CAC

\begin{tabular}{lrrrr}
\hline Properties & \multicolumn{1}{c}{ MLR } & \multicolumn{1}{c}{ MLA } & \multicolumn{1}{c}{ MLB } & \multicolumn{1}{c}{ CAC } \\
\hline Moisture \% & $8.08 \pm 0.04$ & $4.12 \pm 0.06$ & $5.88 \pm 0.03$ & $6.67 \pm 0.07$ \\
Ash \% & $12.71 \pm 0.47$ & $5.43 \pm 0.50$ & $8.42 \pm 0.49$ & $7.10 \pm 0.01$ \\
Volatile \% & $36.45 \pm 0.03$ & $21.31 \pm 0.50$ & $32.97 \pm 0.49$ & $17.50 \pm 0.03$ \\
Fixed carbon \% & $42.76 \pm 0.02$ & $69.14 \pm 0.01$ & $52.49 \pm 0.04$ & $68.73 \pm 0.05$ \\
Iodine number & $92.24 \pm 0.05$ & $182.29 \pm 0.05$ & $169.18 \pm 0.20$ & $200.36 \pm 0.30$ \\
pH & $7.08 \pm 0.02$ & $6.95 \pm 0.02$ & $7.02 \pm 0.03$ & $7.0 \pm 0.01$ \\
\hline
\end{tabular}

MLR raw Moringa oleifera, MLA acid activated Moringa oleifera, MLB base activated Moringa oleifera, CAC Commercial activated carbon 
bulk density is another important physical parameter, especially when an activated carbon product is to be investigated for its filterability. This is because it determines the mass of carbon that can be contained in a filter of given solid capacity and the amount of treated liquid that can be retained by the filter cake (Okieimen et al. 2007).

\section{Fourier Transform Infra-Red (FTIR) Spectra of different adsorbents}

Figures 1, 2 and 3 reveal the FTIR spectra of M. oleifera, where the peaks were slightly shifted. This shift in peak values may be due to the formation of chemical bond between functional groups present on M. oleifera; the same observations are reported (Al-Ghouti et al. 2003; Bekci et al. 2009; Sekhar et al. 2009). On the basis of the FTIR, one can confirm the potential applicability of adsorption of different pollutants on M. oleifera with sufficient and satisfactory removal efficiency.

As shown in Fig. 2, the FTIR spectroscopic analysis indicated broad band at $3280 \mathrm{~cm}^{-1}$, representing bonded OH groups. The band observed at $2917-2849 \mathrm{~cm}^{-1}$ was assigned to the aliphatic $\mathrm{C}-\mathrm{H}$ group. The peak around $1623 \mathrm{~cm}^{-1}$ corresponds to $\mathrm{C}=\mathrm{O}$ stretch. The peak observed at $1541 \mathrm{~cm}^{-1}$ corresponds to the secondary amine group, while the peak at $1374 \mathrm{~cm}^{-1}$ corresponds to the symmetric bending of $\mathrm{CH}_{3}$; the one observed at $1314 \mathrm{~cm}^{-1}$ corresponds to the $\mathrm{C}-\mathrm{H}$ bending. Also, the peak observed at $1242 \mathrm{~cm}^{-1}$ corresponds to the $-\mathrm{SO}_{3}$ stretching, at $1029 \mathrm{~cm}^{-1}$ corresponds to $\mathrm{C}=\mathrm{O}$ bonds of ether, ester or phenol, at $668 \mathrm{~cm}^{-1}$ corresponds to $-\mathrm{CN}$ stretching, while the peak observed at $564 \mathrm{~cm}^{-1}$ corresponds to S-O. As seen in Figs. 1 and 2, the spectral analysis of raw $M$. oleifera and acid activated $M$. oleifera indicated that mostly the bonded $-\mathrm{OH}$ groups, $\mathrm{C}=\mathrm{O}$ stretching, and secondary amine group will be involved in adsorption process. There were clear band shifts and intensity decrease of the band at 1632, 1561, 1381, 1048, 584,513 $\mathrm{cm}^{-1}$. The changes in FTIR spectra confirmed the effects of acid activation on raw M. oleifera leaves (Fig. 1). The shifts in the spectra show that $M$. oleifera leaves will be a useful adsorbent in the removal of dyes and heavy metals. The same observations were reported (Al-Ghouti et al. 2003; Bekci et al. 2009; Sekhar et al. 2009).

As also shown in Fig. 3, the FTIR spectroscopic analysis indicated broad band at $3276 \mathrm{~cm}^{-1}$, representing bonded -OH groups. The band observed at about $2918-2850 \mathrm{~cm}^{-1}$ was assigned to the aliphatic $\mathrm{C}-\mathrm{H}$ group. The peak around $1604 \mathrm{~cm}^{-1}$ corresponds to the $\mathrm{C}=\mathrm{O}$ stretch. The peak observed around $1375 \mathrm{~cm}^{-1}$ corresponds to the symmetric bending of $\mathrm{CH}_{3}$, while the peak observed at $1314 \mathrm{~cm}^{-1}$ corresponds to the $\mathrm{C}-\mathrm{H}$ bending. Moreso, the peak observed at $1012 \mathrm{~cm}^{-1}$ corresponds to $\mathrm{C}=\mathrm{O}$ bonds of ether, ester or phenol. The peak observed at $633 \mathrm{~cm}^{-1}$ corresponds to $-\mathrm{CN}$ stretching and the peak observed at $594 \mathrm{~cm}^{-1}$ corresponds to $\mathrm{S}-\mathrm{O}$. As seen in Figs. 1 and 3, the spectral analysis of raw M. oleifera and base activated $M$. oleifera indicated that mostly the bonded $-\mathrm{OH}$ groups, and $\mathrm{C}=\mathrm{O}$ stretching will be involved in adsorption. There were clear band shifts and intensity decrease at 3280, 1632, 1381, 1048, 664, $513 \mathrm{~cm}^{-1}$, respectively. The changes in FTIR spectra confirmed the effect of base activation on raw M. oleifera (Fig. 1). The shifts in the spectra show that M. oleifera leaves will be a useful adsorbent in the removal of dyes and heavy metals. This also correlates with many other works reported in the literatures (Al-Ghouti et al. 2003; Bekci et al. 2009; Sekhar et al. 2009).

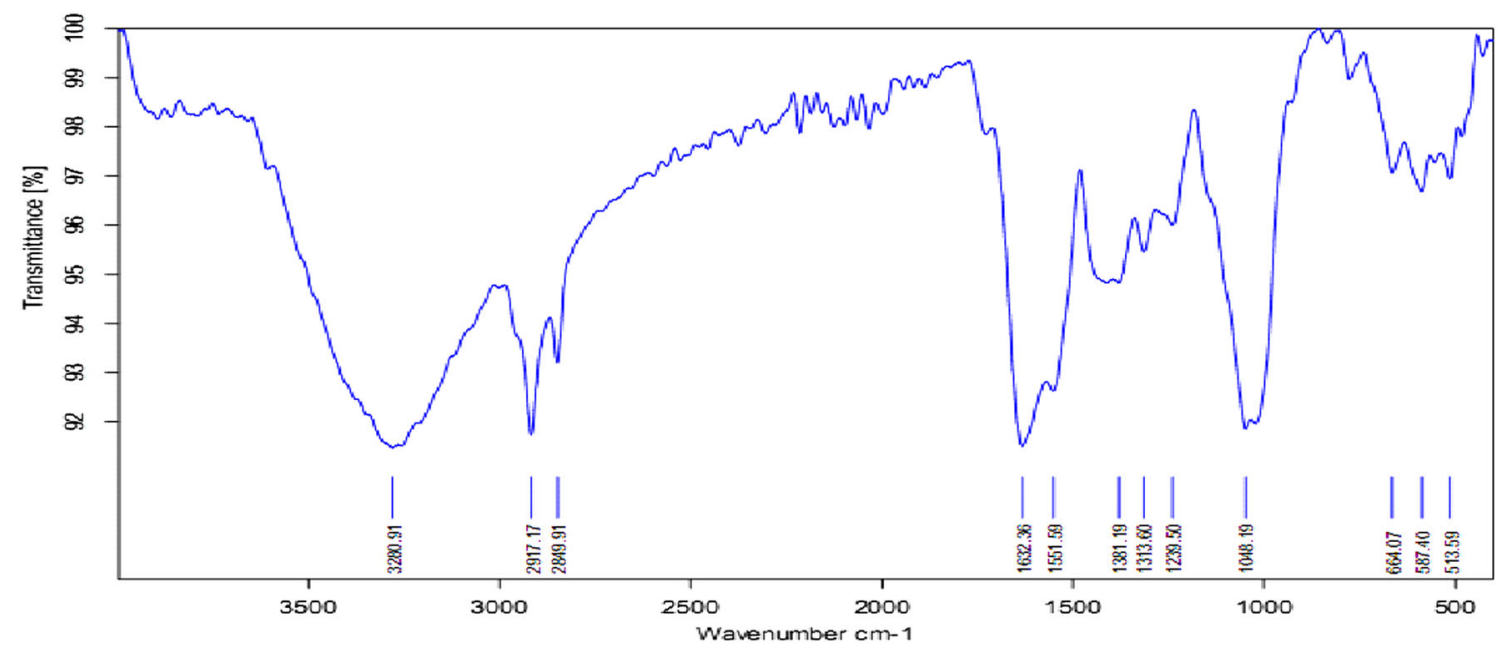

Fig. 1 FTIR of raw Moringa olefera (MLR) 


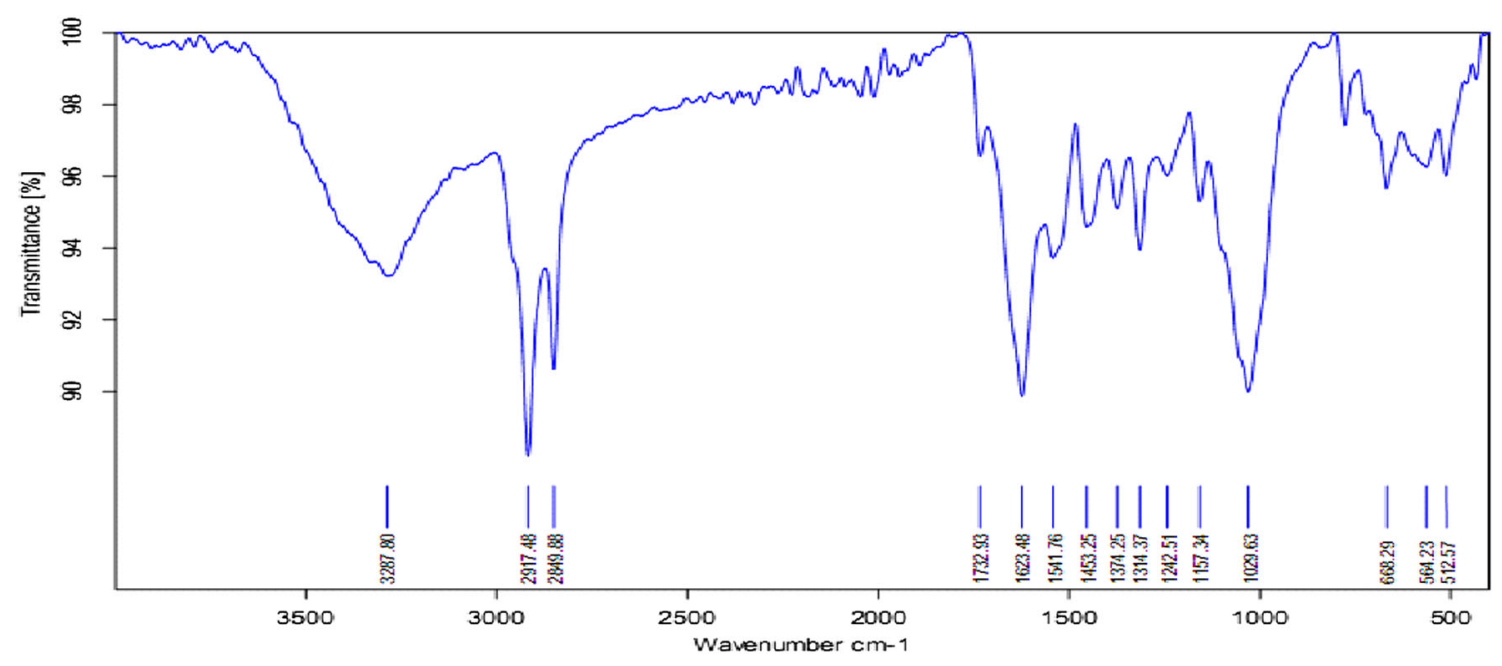

Fig. 2 FTIR of acid activated Moringa olefera (MLA)

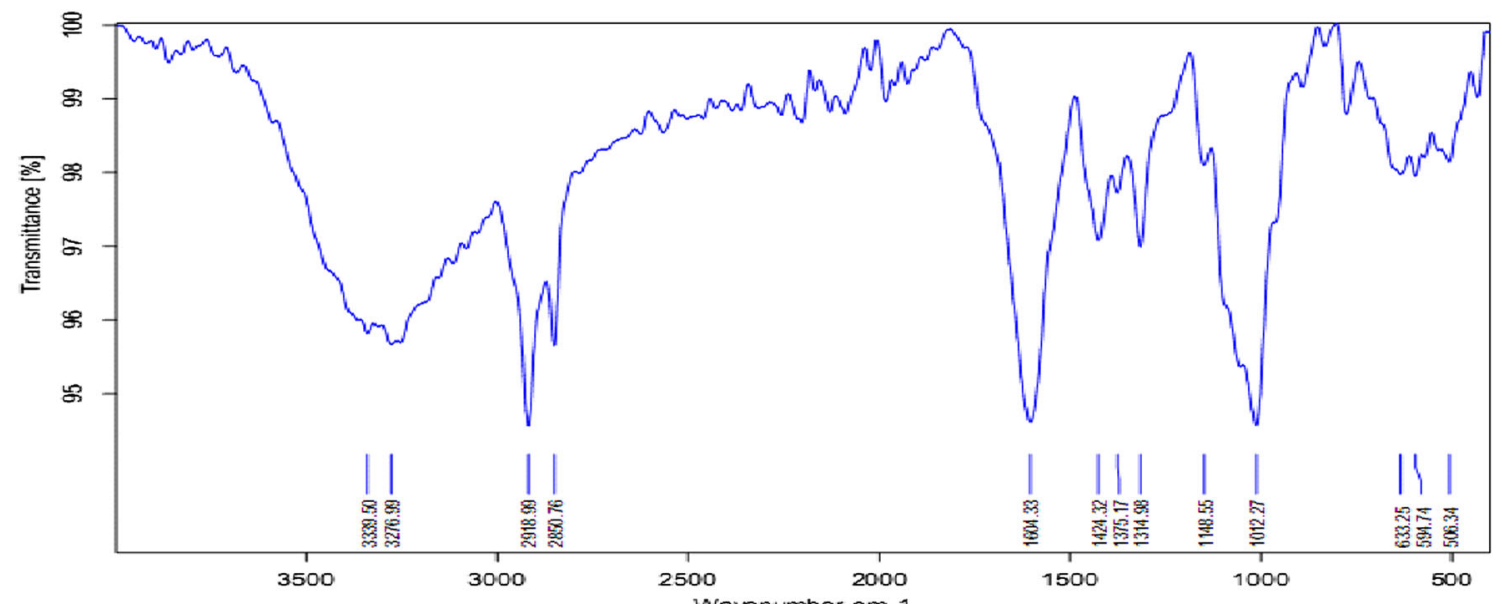

Fig. 3 FTIR of base activated Moringa olefera (MLB)

\section{Scanning electron micrographs of Moringa Olifera}

Activated carbon is referred to as a good adsorbent because of its high degree of porosity and an extensive surface area. The adsorption capacity of activated carbon is determined not only by the textural properties but also by the chemical nature of its surface. The surface of activated carbon contains a number of oxygen containing functional groups. The nature of surface area of any activated carbon can be altered by different treatments (Al-Ghouti et al. 2003; Santhi et al. 2010).

The surface morphology of MLR and MLA and MLB is shown in Fig. 4a-c. The surface structures of both precursors were rough and uneven. MLA and MLB have several pores due to the modification using an activating agent. A significant pore structure exists with a series of rough cavities distributed over the surface of MLA and MLB. This was due to the breakdown of the lignocellulosic material at high temperature followed by the evaporation of volatile compounds leaving samples with well-developed pores. During the activation process, the $\mathrm{C}-\mathrm{KOH}$ reaction rate was increased, thus resulting in carbon 'burn off', thereby developing good pores on the sample. The $\mathrm{C}-\mathrm{KOH}$ reaction also increased the porosity of MLA and MLB as well as creating new pores due to the loss of volatile components, carbon in the form of $\mathrm{CO}$ and $\mathrm{CO}_{2}$ (Auta and Hameed 2011). The physiochemical treatment was able to produce porous adsorbent, thus increasing the surface area. Kilic et al. (2011) found out that the $\mathrm{KOH}$ assists in widening the porosity of tobacco residue AC. The tobacco residue was found to have very little porosity, whereas the surface structure of MLA and MLB was full cavities. Physiochemical activation of $M$. oleifera produces porous adsorbent, therefore, resulting in increased adsorbate uptake which would be of great value in the adsorption process. 


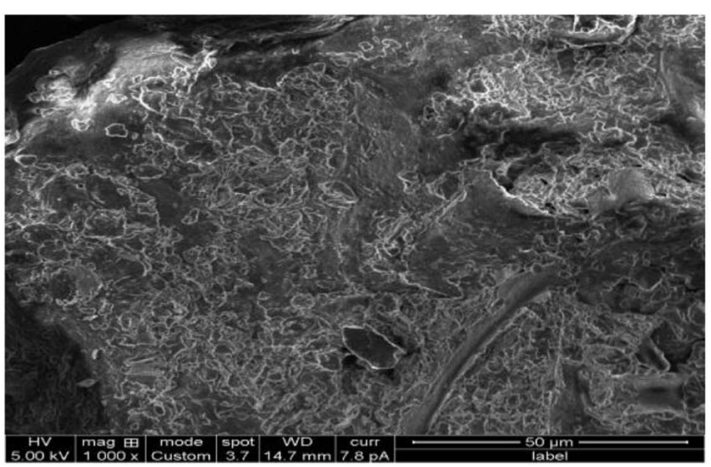

(a) MLR

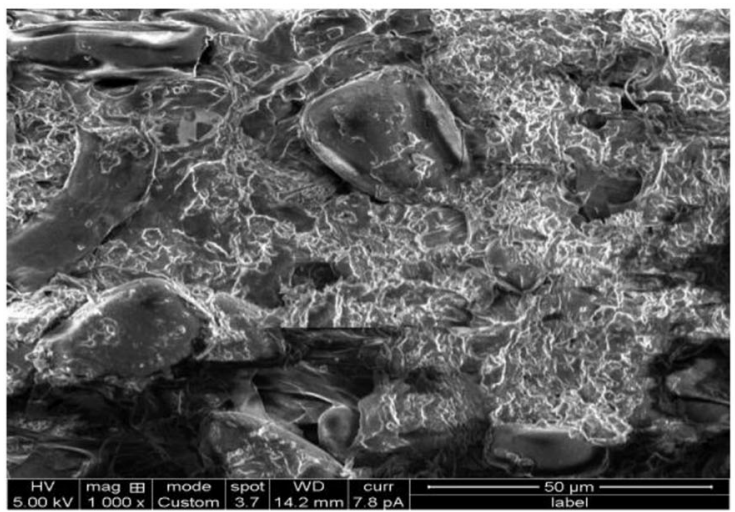

(b) MLA

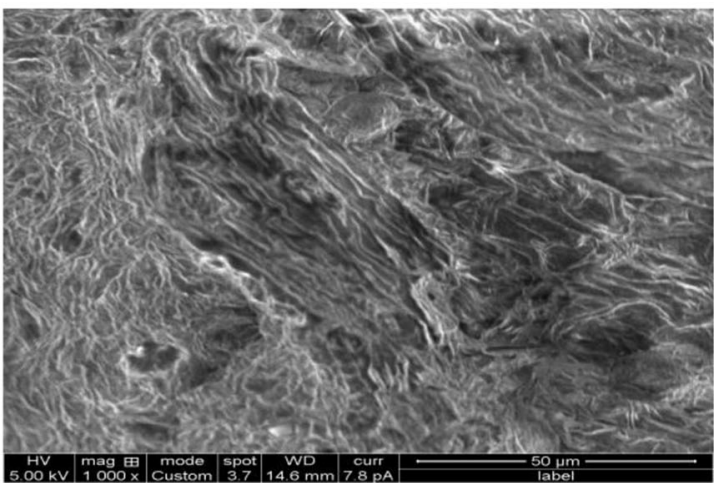

(c) MLB

Fig. 4 The SEM micrographs and Energy dispersive X-ray (EDX) of a raw Moringa olefera, $\mathbf{b}$ acid activated Moringa oleifera and $\mathbf{c}$ base activated Moringa olefera (magnification $\times 1000$ ) and energy

In Fig. 4a-c, the SEM images of the raw, base and acid activated $M$. oleifera, respectively, several large pores in a honeycomb shape were found on the surface of acid activated $M$. oleifera compared to both raw and base activated $M$. oleifera. This shows that the acid activation process is more effective in creating well-developed pores on the surface of the raw sample, leading to a large surface area and porous structure of MLA. Similar observations were observed by Ricou-Hoeffer et al. (2001) and Hameed and Daud (2008). These pores

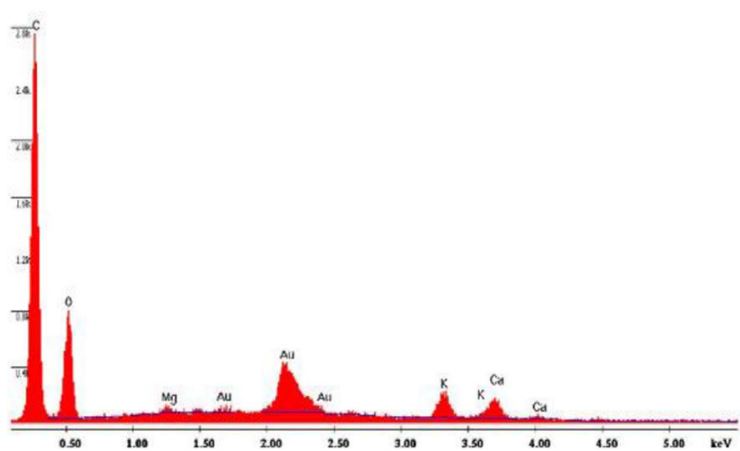

(d) MLR

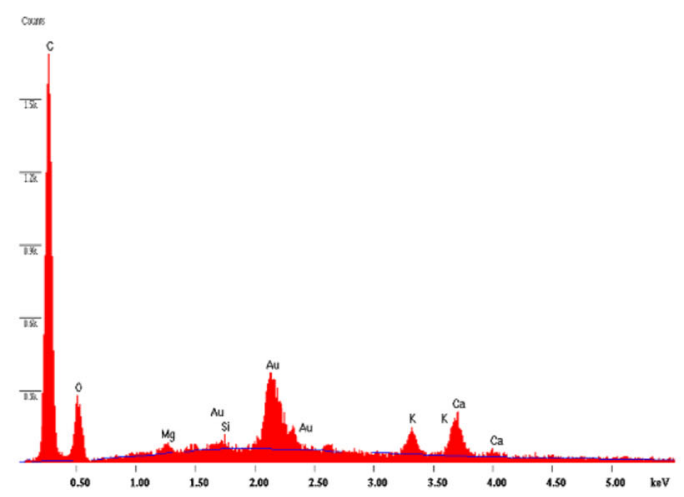

(e) MLA

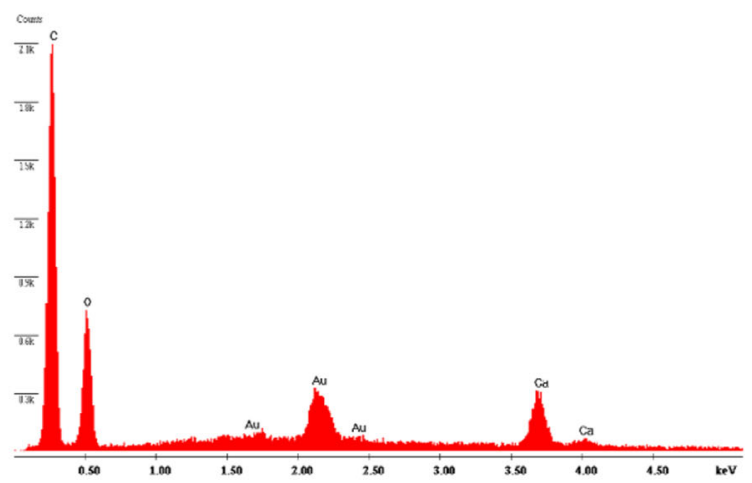

(f) MLB

dispersive X-ray (EDX) of $\mathbf{d}$ raw Moringa olefera, e acid activated Moringa oleifera and $\mathbf{f}$ base activated Moringa olefera (magnification $\times 1000)$

provided a good surface for dyes, heavy metals and waste effluents to be trapped and adsorbed into (Bello and Ahmad 2011a, b, c, d). Porosity describes the number of pores present in a sample. It enhances the adsorption capacity of the adsorbent. From Table 1, porosity is in the order MLA $>$ MLB $>$ CAC. This is in agreement with other findings reported in literature (Al-Ghouti et al. 2003; Okieimen et al. 2007; Santhi et al. 2010a; Saha et al. 2010, Ekpete and Horsfall 2011; Bello and Ahmad $2011 \mathrm{a}, \mathrm{b}, \mathrm{c}, \mathrm{d})$. 


\section{Energy dispersive X-ray (EDX)}

The chemical analysis using EDX technique consists of detection of those protons using a solid detector $\mathrm{Si}-\mathrm{Li}$ (detection by energy dispersion). The energy of these photons, $X$, is characteristic of its atoms. A line spectrum (peak) is obtained, each corresponding to the photons $X$ of a given energy, representing a given element. The intensity of the characteristic lines is proportional to the concentration of the element in the analytical volume; this analysis is quantitative (Fig. $4 \mathrm{~d}-\mathrm{f}$ ). However, there is a factor of correction depending on the experimental parameters (energy of the incidental beam, its angle) and the sample composition. Thus, only a semi-quantitative analysis is considered. The detection limit is situated at the concentrations of $0.1-1 \%$ (for elements having average or light atomic weight with the exception of unfavorable superposition of characteristic peaks). The detector allows detection of light elements $(\mathrm{C}, \mathrm{O}, \mathrm{Ca}, \mathrm{N})$ and even at limited degree: boron, but the yield is very weak because the photons of boron are absorbed by the window which protects the detector (Fig. 4d-f).
The EDX result of raw, acid and base activated $M$. oleifera presented in Tables 2, 3 and 4 showing the differences between the amount of carbon and oxygen in the samples. The sample with the highest amount of carbon and the least amount of oxygen is said to be the most effective. The meaning of this is that, the higher the amount of carbon present in the sample, the lower is the amount of oxygen. According to the Tables 2, 3 and 4, it was observed that the acid activated M. oleifera (MLA) has the highest amount of carbon by weight $(69.40 \%)$ and $(76.11 \%)$ by atom and the lowest amount of oxygen followed by the base activated sample while raw $M$. oleifera (MLR) has the least percentage by weight of carbon. The implication of this is that only the sample that is rich in carbon content can be an efficient adsorbent for the removal of dyes, heavy metals and other organic pollutants from aqueous solution (Xiong et al. 2013, 2014). This results (Tables 2, 3, 4) show that the most effective adsorbent among those prepared is MLA. This is consistent with the conclusions obtained by Hanumantharao et al. (2012), Negrea et al. (2013), Xiong et al. (2013, 2014).

Table 2 EDX result of raw Moringa oleifera (MLR)

\begin{tabular}{lrrrrrr}
\hline Element & Wt\% & \multicolumn{1}{c}{ At\% } & $K$-ratio & $Z$ & $A$ & \multicolumn{1}{c}{ Z } \\
\hline C & 60.45 & 70.40 & 0.4280 & 1.0151 & 0.6972 & 1.0002 \\
O & 29.98 & 26.21 & 0.0666 & 0.9961 & 0.2232 & 1.0000 \\
K & 5.83 & 2.09 & 0.0528 & 0.8955 & 1.0187 & 1.0114 \\
Ca & 3.74 & 1.30 & 0.0342 & 0.9142 & 1.0027 \\
Total & 100.00 & 100.00 & & & \\
\hline
\end{tabular}

Table 3 EDX result of acid activated Moringa oleifera (MLA)

\begin{tabular}{|c|c|c|c|c|c|c|}
\hline Element & $\mathrm{Wt} \%$ & At $\%$ & $K$-ratio & $Z$ & $A$ & $F$ \\
\hline C & 64.90 & 76.11 & 0.4690 & 1.0157 & 0.7113 & 1.0002 \\
\hline $\mathrm{O}$ & 21.84 & 19.23 & 0.0422 & 0.9966 & 0.1939 & 1.0000 \\
\hline $\mathrm{Ca}$ & 13.26 & 4.66 & 0.1238 & 1.0203 & 1.0203 & 1.0000 \\
\hline Total & 100.00 & 100.00 & & & & \\
\hline
\end{tabular}

Table 4 EDX result of base activated Moringa oleifera (MLB)

\begin{tabular}{lrrrrrr}
\hline Element & \multicolumn{1}{c}{ Wt\% } & \multicolumn{1}{c}{ At\% } & $K$-ratio & $Z$ & $A$ \\
\hline $\mathrm{C}$ & 64.03 & 73.31 & 0.4595 & 1.0124 & 0.7087 & 1.0003 \\
$\mathrm{O}$ & 27.77 & 23.87 & 0.0598 & 0.9933 & 0.2169 & 1.0000 \\
$\mathrm{Ca}$ & 8.19 & 2.87 & 0.0762 & 0.9116 & 1.0205 & 1.0000 \\
Total & 100.00 & 100.00 & & & \\
\hline
\end{tabular}




\section{Conclusion}

In this research, a newly prepared activated carbon derived from M. oleifera compared favorably well with the CAC. FTIR, elemental analyses, TGA, SEM and EDX results indicate that the impregnation of acid $\left(\mathrm{H}_{2} \mathrm{SO}_{4}\right)$ and base $(\mathrm{NaOH})$ onto $M$. oleifera is feasible with MLA yielding the best results possible. The material offers the versatility to remove different dyes, metal ions and other organic pollutants due to the presence of an increased pore size and surface area after activation. Furthermore, the results of the present investigation show that MLA is a good precursor for preparation of potentially useful adsorbent for the separation of dyes, metal ions and other organic pollutants from aqueous solutions. In conclusion, $M$. oleifera leaf can satisfactorily be considered as an alternative material for separation applications and recovery of dyes and heavy metals from aqueous solutions.

Acknowledgments The corresponding author acknowledges the support obtained from Third World Academy of Science (TWAS) in the form of Grant; Research Grant no. 11-249 RG/CHE/AF/ AC_1_UNESCO FR: 3240262674.

Open Access This article is distributed under the terms of the Creative Commons Attribution 4.0 International License (http:// creativecommons.org/licenses/by/4.0/), which permits unrestricted use, distribution, and reproduction in any medium, provided you give appropriate credit to the original author(s) and the source, provide a link to the Creative Commons license, and indicate if changes were made.

\section{References}

Acharya J, Sahu JN, Sahoo BK, Mohant CR, Meikap BC (2009) Removal of chromium (VI) from wastewater by activated carbon developed from Tamarind wood activated with zinc chloride. Chem Eng J 150:25-39

Adowei P, Horsfall M Jr, Spiff AI (2012) Adsorption of methyl red from aqueous solution by activated carbon produced from cassava (Manihot esculenta Cranz) peel waste. Innov Sci Eng 2(2):24-33

Ahmad MA, Alrozi R (2010) Optimization of preparation conditions for mangosteen peel-based activated carbons for the removal of Remazol Brilliant Blue $\mathrm{R}$ using response surface methodology. Chem Eng J 165:883-890

Ahmad MA, Rahman NK (2011) Equilibrium, kinetics and thermodynamic of Remazol Brilliant Orange 3R dye adsorption on coffee husk-based activated carbon. Chem Eng J 170:154-161

Ahmedna M, Marshall WE, Rao RM (2000) Granular activated carbons from agricultural by-products: preparation properties and application in cane sugar refining. Bull Louisana State Univ Agric Centre, 54

Al-Ghouti MA, Khraisheh MAM, Allen SJ, Ahmad MN (2003) The removal of dyes from textile wastewater: a study of the physical characteristics and adsorption mechanisms of diatomaceous earth. J Environ Manag 69:229
Al-Othman ZA, Habila MA, Ali R, Ghafar AA, Hassouna MSED (2013) Valorization of two waste streams into activated carbon and studying its adsorption kinetics equilibriumisotherms and thermodynamics for methylene blue removal. Arab J Chem 2:2-12. doi:10.1016/j.arabjc.(2013).05.007

Anjorin ST, Ikokoh PS, Okolo A (2010) Mineral composition of Moringa oleifera Leaves Pods and seeds from two regions in Abuja, Nigeria. Int J Agric Biol 12(3):1560-1569

Aslam MF, Anwar R, Nadeem U, Rashid TG, Kazi A, Nadeem M (2005) Mineral composition of Moringa oleifera leaves and pods from different regions of Punjab, Pakistan. Asian J Plant Sci 4:417-421

Auta M, Hameed BH (2011) Optimized waste tea activated carbon for adsorption of methylene blue and acid blue 29 dyes using response surface methodology. Chem Eng J 175:233-243

Banerjee S, Chattopadhyaya MC (2013) Adsorption characteristics for the removal of a toxic dye tartrazine from aqueous solutions by a low cost agricultural by-product. Arab J Chem. doi:10.1016/ j.arabjc.(2013).06.005

Bekci Z, Seki Y, Cavas L (2009) Removal of malachite green by using an invasive marine alga Caulerpa racemosa var. Cylindracea. J Hazard Mater 161:1454-1460

Bello OS (2013) Adsorptive removal of Malachite Green with activated carbon prepared from oil palm fruit fibre by $\mathrm{KOH}$ activation and $\mathrm{CO}_{2}$ gasification. S Afr J Chem 66:32-41

Bello OS, Ahmad MA (2011a) Response surface modeling and optimization of Remazol Brilliant Blue reactive dye removal using periwinkle shell-based activated carbon. Sep Sci Technol 46(5):2367-2379

Bello OS, Ahmad MA (2011b) Adsorption of dyes from aqueous solution using chemical activated mango peels. In: 2nd International conference on environmental science and technology (ICEST), vol 2, pp 108-113

Bello OS, Ahmad MA (2011c) Adsorptive removal of a synthetic textile dye using coca pod husks. Toxicol Environ Chem 93:1298-1308

Bello OS, Ahmad MA (2011d) Removal of remazol brilliant violet5R dye using periwinkle shell. Chem Ecol 27:481-492

Bello OS, Ahmad MA (2012a) Preparation and characterization of activated carbon derived from rubber seed coat. Bulg J Sci Edu 21:389-395

Bello OS, Ahmad MA (2012b) Coconut (Cocos nucifera) shell based activated carbon for the removal of malachite green dye from aqueous solutions. Sep Sci Technol 47:903-912

Bello OS, Ahmad MA, Siang TT (2011) Utilization of cocoa pod husk for the removal of Remazol Black B Reactive dye from aqueous solutions: kinetic, equilibrium and thermodynamic studies. Trends Appl Sci Res 6(8):794-812

Bello OS, Semire B (2012) Equilibrium, kinetic and quantum chemical studies on the adsorption of Congo red using Imperata cylindrica leaf powder activated carbon. Toxicol Environ Chem 94:1114-1124

Bello OS, Adeogun IA, Ajaelu JC (2008) Adsorption of methylene blue onto activated carbon derived from periwinkle shells: kinetics and equilibrium studies. Chem Ecol 24:285-295

Bello OS, Ahmad MA, Ahmad N (2012a) Adsorptive features of banana (Musa paradisiaca) stalk-based activated carbon for malachite green dye removal. Chem Ecol 28:153-167

Bello OS, Fatona TA, Falaye FS, Osuolale OM, Njoku VO (2012b) Adsorption of eosin dye from aqueous solution using groundnut hull-based activated carbon: kinetic, equilibrium, and thermodynamic studies. Environ Eng Sci 29:186-194

Bello OS, Olusegun OA, Njoku VO (2013a) Fly ash: an alternative to powdered activated carbon for the removal of eosin dye from aqueous solutions. Bull Chem Soc Ethiop 27(2):191-204

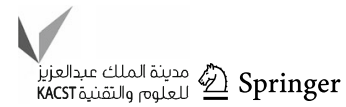


Bello OS, Auta M, Ayodele OB (2013b) Ackee apple (Blighia sapida) seeds: a novel adsorbent for the removal of Congo Red dye from aqueous solutions. Chem Ecol 29:58-71

Chiou M, Chuang G (2006) Competitive adsorption of dye metanil yellow and RB15 in acid solutions on chemically cross-linked chitosan beads. Chemosphere 62:731-740

Demirbas E, Kobya M, Sulak MT (2008) Adsorption kinetics of a basic dye from aqueous solutions onto apricot stone activated carbon. Bioresour Technol 99:5368-5373

Ekpete OA, Jnr Horsfall M (2011) Preparation and characterization of activated carbon derived from fluted pumpkin stem waste (Telfairia occidentalis Hook F) Res. J Chem Sci 1(3):10-17

Ekpete OA, Horsfall M Jr, Tarawou T (2011) Sorption kinetic study on the removal of phenol using fluted pumpkin and commercial activated carbon. Int J Biol Chem Sci 5(3):1143-1152

Foo KY, Hameed BH (2012) Coconut husk derived activated carbon via microwave induced activation: effects of activation agents, preparation parameters and adsorption performance. Chem Eng J 184:57-65

Gecgel U, Kolancilar H (2012) Adsorption of Remazol brilliant blue $\mathrm{R}$ on activated carbon prepared from a pine cone. Nat Prod Res 26:659-664

Ghaedi M, Sadeghian B, Pebdani AA, Sahraei R, Daneshfar A, Duran C (2012) Kinetics, thermodynamics and equilibrium evaluation of direct yellow 12 removal by adsorption onto silver nanoparticles loaded activated carbon. Chem Eng J 187:133-141

Ghaedi M, Ansari A, Sahraei R (2013) ZnS:Cu nanoparticles loaded on activated carbon as novel adsorbent for kinetic, thermodynamic and isotherm studies of reactive orange 12 and direct yellow 12 adsorption. Spectrochim Acta A Mol Biomol Spectrosc 114:687-694

Gimba C, Musa I (2007) Preparation of activated carbon from agricultural waste: cyanide binding with activated carbon matrix from coconut shell. J Chem Nigeria 32:167-170

Gupta VK, Nayak A (2012) Cadmium removal and recovery from aqueous solution by novel adsorbents prepared from orange peel and $\mathrm{Fe}_{2} \mathrm{O}_{3}$ nanoparticles. Chem Eng J 180:81-90

Gupta VK, Agarwal S, Saleh TA (2011a) Synthesis and characterization of alumina coated carbon nanotube and their application on lead removal. J Hazard Mater 185(15):17-23

Gupta VK, Jain R, Nayaka A, Agarwal S, Shrivastava M (2011b) Removal of the hazardous dye-tartrazine by photodegradation on titanium dioxide surface. Mater Sci Eng, C 31:1062-1067

Gupta VK, Ali I, Saleh TA, Nayaka A, Agarwal S (2012a) Chemical treatment technologies for waste-water recycling-an overview. RSC Adv 2(16):6380-6388

Gupta VK, Jain R, Mittal A, Saleh TA, Nayak A, Agarwal S, Sikarwar $\mathrm{S}$ (2012b) Photo-catalytic degradation of toxic dye amaranth on $\mathrm{TiO}_{2} / \mathrm{UV}$ in aqueous suspension. Mater Sci Eng, C 32(1):12-17

Hajati S, Ghaedi M, Karimi F, Barazesh B, Sahraei R, Daneshfar A (2014) Competitive adsorption of direct yellow 12 and reactive o12 on ZnS: Mn nanoparticles loaded on activated carbon as novel adsorbent. J Ind Eng Chem 20:564-571

Hameed BH, Daud FBM (2008) Adsorption studies of basic dye on activated carbon derived from agricultural waste: Hevea brasiliensis seed coat. Chem Eng J 139:48-55

Hameed KS, Muthirulan P, Meenakshi SM (2013) Adsorption of chromotrope dye onto activated carbons obtained from the seeds of various plants: equilibrium and kinetics studies. Arab J Chem. doi:10.1016/j.arabjc.2013.07.058

Hanumantharao Y, Kishore M, Ravindhranath K (2012) Characterization and adsorption studies of "Lagenaria siceraria" shell carbon for the removal of fluoride. Int $\mathrm{J}$ Chem Tech Res 4(4):1686-1700

Ho CT (1994) Food phytochemicals and cancer prevention. In: ACS symposium series 547. American Chemical Associaton, Washington DC, pp 132-144
Horsfall Jnr M, Abia AA, Spiff AI (2003) A removal of $\mathrm{Cu}^{2+}$ and $\mathrm{Zn}^{2+}$ ions from wastewater by cassava (Manichol esculentus cranz) Waste Biomass. Afr J Biotechnol 2:969-976

Hsu R, Midcap S, Arbainsyah, De Witte L (2006) Moringa oleifera; medicinal and socioeconomic uses. International Course on Economic Botany, September 2006. National Herbarium, Leiden

Iqbal MJ, Ashiq MN (2007) Adsorption of dyes from aqueous solutions on activated charcoal. J Hazard Mater 139:57-66

Jain AK, Gupta VK, Bhatnagar A, Suhas A (2003) A comparative study of adsorbents prepared from industrial wastes for removal of dyes. Sep Sci Technol 38(2):463-481

Kansal SK, Kumari A (2014) Potential of M. oleifera for the treatment of water and wastewater. Chem Rev 114(9):4993-5010

Karthikeyan S, Gupta VK, Boopathy R, Titus A, Sekaran G (2012) A new approach for the degradation of high concentration of aromatic amine by heterocatalytic fenton oxidation: kinetic and spectroscopic studies. J Mol Liquids 173:153-163

Khaled A, El Nemr A, Ei-Sikaily A, Abdelwahab A (2009) Treatment of artificial textile dye effluent containing direct yellow 12 by orange peel carbon. Desalination 238:210-232

Kilic M, Apaydin-Varol E, Pütün AE (2011) Adsorptive removal of phenol from aqueous solutions on activated carbon prepared from tobacco residues: equilibrium, kinetics and thermodynamics. J Hazard Mater 189:397-403

Kismir Y, Aroguz AZ (2011) Adsorption characteristics of the hazardous dye brilliant green on Saklikent mud. Chem Eng J 172:199-206

Liou TH (2010) Development of mesoporous structure and high adsorption capacity of biomass-based activated carbon by phosphoric acid and zinc chloride activation. Chem Eng J 158:129-142

Mittal A, Kaur D, Malviya A, Mittal J, Gupta VK (2009a) Adsorption studies on the removal colouring agent phenol red from wastewater using waste material as adsorbents. J Colloid Interface Sci 337(2):345-354

Mittal A, Mittal J, Malviya A, Gupta VK (2009b) Adsorptive removal of hazardous anionic dye Congo Red from wastewater using waste materials and recovery by desorption. J Colloid Interface Sci 340(1):16-26

Mittal A, Mittal J, Malviya A, Gupta VK (2010a) Removal and recovery of Chrysoidine $\mathrm{Y}$ from aqueous solution by waste materials. J Colloid Interface Sci 344(2):497-507

Mittal A, Mittal J, Malviya A, Kaur D, Gupta VK (2010b) Decolouration treatment of a hazardous triarylmethane dye, light green SF (yellowish) by waste material adsorbents. J Colloid Interface Sci 342(2):518-527

Namasivayam C, Kavitha D (2002) Removal of Congo Red from water by adsorption onto activated carbon prepared from coir pith, an agricultural solid waste. Dyes Pigments 54:47-58

Negrea A, Lupa L, Ciopec M, Negrea P (2013) Characterization of strontium adsorption from aqueous solutions using inorganic materials impregnated with ionic liquid. Int J Chem Eng Appl 4(5):326-331

Okieimen FE, Okiemen CO, Wuana RA (2007) Preparation and characterization of activated carbon from rice husks. J Chem Soc 32:126-136

Reddy DHK, Harinath Y, Seshaiah K, Reddy AVR (2010) Biosorption of $\mathrm{Pb}$ (II) from aqueous solutions using chemically modified Moringa oleifera tree. Chem Eng J 162(2):626-634

Ricou-Hoeffer P, Lecuyer I, Cloirec PL (2001) Experimental design methodology applied to adsorption of metallic ions onto fly ash. Water Res 35:965

Royer B, Cardoso NF, Lima EC, Vaghetti JP, Simon NM, Calvete T, Veses RC (2009) Applications of Brazilian pine-fruit shell in natural and carbonized forms as adsorbents to removal of 
methylene blue from aqueous solutions: kinetic and equilibrium study. J Hazard Mater 164:1213-1222

Saha P, Chowdhury S, Gupta S, Kumar I, Kumar R (2010) Assessment on the removal of malachite green using tamarind fruit shell as biosorbent. Clean Soil Air Water 38(5-6):437-445

Saleh TA, Gupta VK (2012a) Column with CNT/magnesium oxide composite for lead(II) removal from water. Environ Sci Pollut Res 19(4):1224-1228

Saleh TA, Gupta VK (2012b) Photo-catalyzed degradation of hazardous Dye Methyl orange by use of a composite catalyst consisting of multiwalled carbon nanotubes and titanium dioxide. J. Colloids Interface Sci. 371:101-106

Santhi T, Manonmani S, Smitha T (2010) Removal of malachite green from aqueous solution by activated carbon prepared from the epicarp of Ricinus communis by adsorption. J Hazard Mater 179:178-186

Sekhar CP, Kalidhasan S, Rajesh V, Rajesh N (2009) Biopolymer adsorbent for the removal of malachite green from aqueous solution. Chemosphere 77:842-847

Senthilkumaar S, Kalaamani P, Subburaam CV (2006) Liquid phase adsorption of crystal violet onto activated carbons derived from male flowers of coconut tree. J Hazard Mater 136:800-808

Siddhuraju P, Becker K (2003) Antioxidant properties of various solvent extracts of total phenolic constituents from three different agroclimatic origins of drumstick tree (Moringa oleifera Lam) leaves. J Agric Food Chem 51(8):2144-2155

Tan IW, Ahmad AL, Hameed BH (2008) Adsorption of basic dye using activated carbon prepared from oil palm shell: batch and fixed bed studies. Desalination 225:13-28

Tarawou T, Horsfall M Jr, Jose VL (2007) Adsorption of methyl red by water hyacinth (eichornia crassipes) biomass. Chem Biodivers 4:2236-2245

Thinakaran N, Baskaralingam P, Pulikesi M, Panneerselvam P, Sivanesan S (2008) Removal of acid violet 17 from aqueous solutions by adsorption onto activated carbon prepared from sunflower seed hull. J Hazard Mater 151:316-322
Tsai WT, Chang CY, Lin MC, Chien SF, Sun HF, Hsieh MF (2001) Adsorption of acid dye onto activated carbons prepared from agricultural waste bagasse by $\mathrm{ZnCl}_{2}$ activation. Chemosphere 45:51-58

Visa M, Bogatu C, Duta A (2010) Simultaneous adsorption of dyes and heavy metals from multicomponent solutions using fly ash. Appl Surf Sci 256:5486-5491

Xiong C, Jia Q, Chen X, Wang G, Yao C (2013) Optimization of polyacrylonitrile-2-aminothiazole resin synthesis, characterization, and its adsorption performance and mechanism for removal of $\mathrm{Hg}(\mathrm{II})$ from aqueous solutions. Ind Eng Chem Res 52:4978-4986

Xiong C, Zheng Y, Feng Y, Yao C, Ma C, Zheng X, Jiang J (2014) Preparation of a novel chloromethylated polystyrene-2-amino1,3,4-thiadiazole chelating resin and its adsorption properties and mechanism for separation and recovery of $\mathrm{Pt}(\mathrm{IV})$ from aqueous solutions. J Mater Chem A 2:5379-5386

Yahaya NEM, Pakir MF, Latiff M, Abustan I, Bello OS, Ahmad MA (2010a) Process optimisation for $\mathrm{Zn}$ (II) removal by activated carbon prepared from rice husk using chemical activation. Int $\mathbf{J}$ Eng Technol 10:132-136

Yahaya NEM, Pakir MF, Latiff M, Abustan I, Bello OS, Ahmad MA (2010b) Effect of preparation conditions of activated carbon prepared from rice husk by $\mathrm{CO}_{2}$ activation for removal of $\mathrm{Cu}$ (II) from aqueous solution. Int $\mathrm{J}$ Eng Technol 10:47-51

Yahaya NEM, Pakir MF, Latiff M, Abustan I, Bello OS, Ahmad MA (2011a) Adsorptive removal of $\mathrm{Cu}(\mathrm{II})$ using activated carbon prepared from rice husk by $\mathrm{ZnCl}_{2}$ activation and subsequent gasification with $\mathrm{CO}_{2}$. Int J Eng Technol 11:207-211

Yahaya NEM, Pakir MF, Latiff M, Abustan I, Bello OS, Ahmad MA (2011b) Fixed bed column study for $\mathrm{Cu}(\mathrm{II})$ removal from aqueous solutions using rice husk based activated carbon. Int $\mathbf{J}$ Eng Technol 11:248-252 